\title{
Stress Corrosion Cracking Behavior of Carbon Steel in Aqueous Dipa and in Dipa-Sulfolane-Water Solutions
}

\author{
Z. Andrew Foroulis*
}

* Exxon Research and Engineering Co.

\begin{abstract}
Potentiostatic polarization and slow-strain-rate tests have been used to assess the likelihood of stress corrosion cracking of mild steel immersed in aqueous solutions of di-isopropanolamine (dipa) and in solutions of dipa in tetrahydrothiophene sulfoxide (sulfolane) and water, saturated with $\mathrm{CO}_{2}$ at different potentials and strain rates, at $95^{\circ} \mathrm{C}$. Dipa-sulfolanewater solutions show no tendency for stress corrosion cracking either at the free corrosion potential or at potentials of maximum electrochemical reactivity. However, an aqueous solution of $25 \%$ dipa saturated with $\mathrm{CO}_{2}$ was found to cause transgranular stress corrosion cracking of carbon steel at the potential of $-0.60 \mathrm{~V}$ (SCE) which is located in the region of maximum anodic electrochemical reactivity.
\end{abstract} treating

Key words: corrosion, stress corrosion cracking, carbon steel, dipa, dipa-sulfolane, gas

\section{Introduction}

Aqueous solutions of an alkanolamine e.g. di-isopropanolamine (dipa) or mixtures of an alkanolamine e.g. di-isopropanolamine (dipa) and a physical solvent e.g. tetrahydrothiophene sulfoxide (sulfolane) as an absorption medium have been used for the removal of acid gases $\left(\mathrm{CO}_{2}, \mathrm{H}_{2} \mathrm{~S}\right.$, etc. $)$ from a variety of sour gas streams encountered in the petroleum industry. ${ }^{1) \sim 3)}$ Because of the recent experience of stress corrosion cracking of welded carbon steel equipment in aqueous monoethanolamine (MEA) solutions ${ }^{4)}$ a laboratory study was undertaken to investigate the stress corrosion cracking (SCC) tendency of carbon steel in solutions containing dipa-sulfolane-water and also in aqueous solutions of dipa.

\section{Experimental}

The experimental technique used was the slow-strain-rate test in which smooth tensile specimens are strained to failure at a slow rate in the environment of interest. ${ }^{5}$ ) The apparatus used was a Model No. P-2000 constant extension rate tensile machine purchased from W.T. Specialty Co. of Orient, Ohio. It was equipped

\footnotetext{
* P.O. Box 101 Florham Park, New Jersey 07932,
} U.S.A. with a load cell of $2000 \mathrm{lbs}$. capacity using a Daytronic Model 3170 signal conditioner which fed its output to a Bascon-Turner recorder/ plotter Model 8120T.

The test solution was maintained in a cylindrical Teflon cell of one liter capacity which fitted on and around the test rod via a watertight seal. The cell had a closed Teflon lid equipped with suitable openings for introduction and outflow of purge gas, a platinum counter electrode, a bridge connected to an external saturated calomel reference electrode, a reflux condenser and a thermocouple for temperature control. Heating was achieved with an external heating mantle, and the test temperature was controlled to $\pm 2^{\circ} \mathrm{C}$.

In tests carried out at the free corrosion potential conditions, the potential was monitored continuously. In tests carried out at constant potential (using potentiostatic control), the current was recorded using an ECO instrument Model 560/LOG interface in connection with a strip chart recorder. The stress corrosion test specimens were prepared from cold drawn carbon steel (AISI 1018) rods $0.63 \mathrm{~cm}$ diameter. The rods were cut into $33 \mathrm{~cm}$ long pieces and machined into tensile specimens having a gage diameter of $0.25 \mathrm{~cm}$ and a gage length of 1.27 $\mathrm{cm}$. For the tests carried out in dipa-sulfolane- 
water solutions, the specimens were used in the as received conditions. Specimens used in aqueous-dipa solutions prior to machining were annealed at $980^{\circ} \mathrm{C}$ for one hour followed by cooling in air. Before testing, specimens were rinsed with water and finally degreased with acetone.

In solutions consisting of dipa-sulfolane-water slow-strain-rate tests were carried out in a solution consisting of $45 \mathrm{wt} \%$ di-isopropanolamine (dipa), $40 \mathrm{wt} \%$ tetrahydrothiophene sulfoxide (sulfolane) and $15 \mathrm{wt} \%$ water at $95^{\circ} \mathrm{C}$. Most tests were carried out with the solution saturated with $\mathrm{CO}_{2}$ at atmospheric pressure. During the tests the $\mathrm{CO}_{2}$ gas was continuously bubbled through the test solution. In addition, tests were carried out while the solution was purged with $\mathrm{N}_{2}$. Several tests were also run in an inert parafinic base turbine oil (Tereso 32, product of Exxon Corporation) to simulate the ductile fracture expected in a non-aggressive environment. Tests were carried out at strain rates in the range $2 \times 10^{-7}$ to $1 \times 10^{-6} \mathrm{sec}^{-1}$. These strain rates were selected because experience in this and other laboratories indicated that stress corrosion cracking of carbon steel generally occurs at strain rates between about $10^{-5}$ to $10^{-7} \mathrm{sec}^{-1}$.

Stress corrosion cracking tests were also carried out with aqueous solution of dipa containing $25 \mathrm{wt} \%$ dipa. Tests were carried out at the free corrosion potential and in the potential range $-0.8 \mathrm{~V}$ to $+0.1 \mathrm{~V}$ (SCE). Tests were carried out at strain rates of $2.8 \times 10^{-6}$, and $2 \times$ $10^{-7} \mathrm{sec}^{-1}$. Tests carried out with aqueous dipa solutions were saturated with $\mathrm{CO}_{2}$. One test was also carried out with $40 \%$ dipa-water in a $\mathrm{N}_{2}$ saturated solution.

The fracture and side surfaces of all specimens tested were examined with a scanning electron microscope (SEM) following cathodic cleaning of the specimens using a proprietary alkaline solution (Endox 214).* In addition, metallographic examination of longitudinal sections through the fracture test pieces was also carried out for evidence of side cracks.

The assessment of the results was carried out in terms of the nature of fracture (micro-void coalescence vs. multiple cracking with intergranular or transgranular facets), morphology of side cracks, percent reduction in area, time to failure and maximum nominal stress calculated on the basis of the original cross section area.

\footnotetext{
* Product of Ethone Corp., West Haven, Conn.
}

In order to establish the potential range over which cracking occurs, anodic voltametric scans were run at various sweep rates. The design of electrodes and cell design used for the polarization studies was described previously. ${ }^{8)}$

\section{Results and Discussion}

As discussed elsewhere ${ }^{7), 8)}$ the SCC behavior of carbon steel in alkaline media such as carbonate/bicarbonate solutions and aqueous MEA is likely to occur only in restricted ranges of electrochemical potential. To define the potential range for SCC tendency in aqueous-dipa and the dipa-sulfolane-water solutions, anodic voltametric scans at different speeds were used. Two extreme speeds were used, a high speed of potential sweep of about $\sim 1200 \mathrm{mV} /$ min and a relatively low scan speed of $12 \mathrm{mV} / \mathrm{min}$. Typical curves depicting the anodic scans in $\left(\mathrm{CO}_{2}\right.$ saturated) solution of $25 \%$ dipa in water as well as a solution of $45 \%$ dipa- $40 \%$ sulfolane- $15 \%$ water are shown in Fig. 1 to 2.

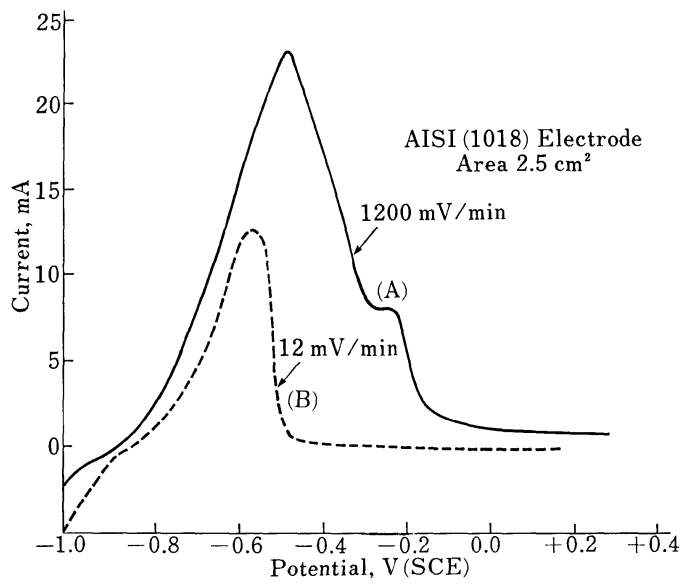

Fig. 1 Voltametric scans at 12 and $1200 \mathrm{mV} / \mathrm{min}$, of carbon steel (AISI 1018) in aqueous $-25 \%$ dipa solution $\mathrm{CO}_{2}$ saturated at $1 \mathrm{~atm} 95^{\circ} \mathrm{C}$.

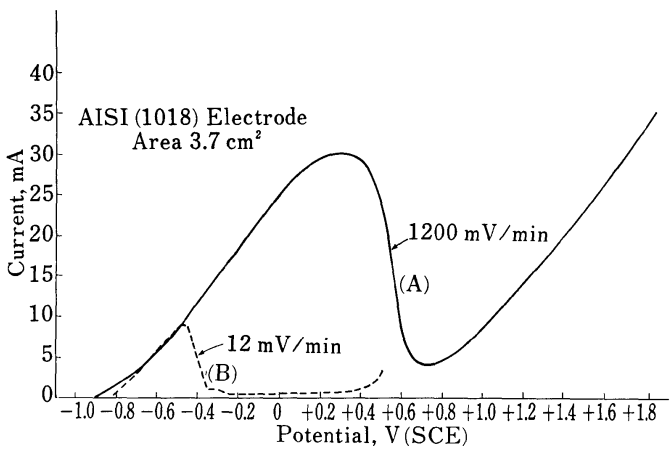

Fig. 2 Voltametric scans at 12 and $1200 \mathrm{mV} / \mathrm{min}$ of carbon steel in $45 \%$ dipa- $40 \%$ sulfolane- $15 \%$ water $\mathrm{CO}_{2}$ saturated $(1 \mathrm{~atm}), 95^{\circ} \mathrm{C}$. 
Table 1 Potential zone of maximum electrochemical reactivity of carbon steel (A1S1 1018) in dipa-water, dipa-sulfolane-water and MEA-water solutions $\mathrm{CO}_{2}$ saturated at $95^{\circ} \mathrm{C}$, 1 atm.

\begin{tabular}{ccc}
\hline Solution & $\begin{array}{c}\text { Potential zone of maximum } \\
\text { electrochemical reactivity, V (SCE) }\end{array}$ & $\begin{array}{c}\text { Maximum anodic current } \\
\text { density, } \mathrm{mA} / \mathrm{cm}^{2} \text { at } 1200 \mathrm{mV} / \mathrm{min}\end{array}$ \\
\hline $25 \%$ Dipa-Water & -0.60 to -0.50 & 9.2 \\
$45 \%$ Dipa- & -0.50 to $+0.2 \mathrm{~V}$ & 8.1 \\
$40 \%$ Sulfolane- & & 35 \\
15\% Water & -0.80 to -0.60 & 35 \\
\hline
\end{tabular}

Table 2 Slow-strain-rate tests of carbon steel (AISI 1018) in 45\%dipa-40\%sulfolane-15\%water solution at $95^{\circ} \mathrm{C}$

\begin{tabular}{|c|c|c|c|c|c|c|c|c|c|c|}
\hline $\begin{array}{l}\text { Test } \\
\text { No. } \\
\end{array}$ & $\begin{array}{c}\text { Solution } \\
\text { Gas (1 Atm) }\end{array}$ & $\begin{array}{l}\text { Potent ia l } \\
\text { V(SCE) } \\
\end{array}$ & $\begin{array}{c}\begin{array}{c}\text { Stra in Rate, } \\
\sec ^{-1}\end{array} \\
\end{array}$ & $\begin{array}{l}\text { Time to } \\
\text { Failure } \\
\text { (hrs) }\end{array}$ & $\begin{array}{l}\text { Maximum } \\
\text { Stress } \\
\text { ksi (kPa) } \\
\end{array}$ & $\begin{array}{c}\text { Reduction } \\
\text { in Area (RA) } \\
(\%)\end{array}$ & $\left(R{\left.\frac{R A}{A}\right)_{\text {inert oil }}}\right.$ & $\begin{array}{c}\text { Solution } \\
\mathrm{pH}\end{array}$ & $\begin{array}{c}\text { Fracture } \\
\text { Surface } \\
\text { Appearance }\end{array}$ & $\begin{array}{l}\text { Secondary } \\
\text { Cracking }\end{array}$ \\
\hline 1 & $\begin{array}{l}\text { Dipa- } \\
\text { Sulfolane- } \\
\text { Water/N2 } \\
\text { Sat'd }\end{array}$ & $\begin{array}{l}E_{\text {corr }} \\
(-0.5 \rightarrow-0.4)\end{array}$ & $2 \times 10^{-6}$ & 22 & $112(772)$ & 40.8 & 0.9 & 10.3 & Ductile & NC \\
\hline 2 & $\begin{array}{l}\text { Dipa- } \\
\text { Sulfolane- } \\
\text { Water/N2 } \\
\text { Sat'd }\end{array}$ & +0.2 & $2 \times 10^{-6}$ & 25.5 & $112(772)$ & 40.8 & 0.9 & 10.3 & Ductile & NC \\
\hline 3 & $\begin{array}{l}\text { Dipa- } \\
\text { Sulfolane- } \\
\text { Water } / \mathrm{CO}_{2} \\
\text { Sat'd }\end{array}$ & $\begin{array}{c}E_{\text {corr }} \\
(-0.55)\end{array}$ & $4 \times 10^{-7}$ & 97.5 & $114(786)$ & 40.8 & 0.9 & 9.7 & Ductile & NC \\
\hline 4 & $\begin{array}{l}\text { Dipa- } \\
\text { Sulfolane- } \\
\text { Water } / \mathrm{CO}_{2} \\
\text { Sat'd }\end{array}$ & $\begin{array}{c}E_{\text {corr }} \\
(-0.47)\end{array}$ & $2 \times 10^{-7}$ & 120 & - & 57.6 & 1.0 & 9.7 & Ductile & NC \\
\hline 5 & $\begin{array}{l}\text { Dipa- } \\
\text { Sulfolane- } \\
\text { Water } / \mathrm{CO}_{2} \\
\text { Sat'd }\end{array}$ & $\begin{array}{c}E_{\text {corr }} \\
(-0.80)\end{array}$ & $1 \times 10^{-6}$ & 37 & $113(779)$ & 36 & 0.8 & 9.7 & Ductile & NC \\
\hline 6 & $\begin{array}{l}\text { Dipa- } \\
\text { Sulfolane- } \\
\text { Water } / \mathrm{CO}_{2} \\
\text { Sat'd }\end{array}$ & $\begin{array}{l}E_{\text {corr }} \\
(-0.2)\end{array}$ & $2 \times 10^{-6}$ & 20.5 & $108(744)$ & 32 & 0.7 & 9.7 & Ductile & NC \\
\hline 7 & $\begin{array}{l}\text { Dipa- } \\
\text { Sulfolane- } \\
\text { Water/ } / \mathrm{CO}_{2} \\
\text { Sat'd }\end{array}$ & $\begin{array}{l}E_{\text {corr }} \\
(-0.4)\end{array}$ & $4 \times 10^{-6}$ & 9.5 & $104(716)$ & 48 & 1.0 & 9.7 & Ductile & NC \\
\hline 8 & $\begin{array}{l}\text { Dipa- } \\
\text { Sulfolane- } \\
\text { Water } / \mathrm{CO}_{2} \\
\text { Sat'd }\end{array}$ & +0.2 & $2 \times 10^{-6}$ & 22 & $112(772)$ & 40.8 & 0.9 & 9.7 & Ductile & MT \\
\hline 9 & $\begin{array}{l}\text { Dipa- } \\
\text { Sulfolane- } \\
\text { Water } / \mathrm{CO}_{2} \\
\text { Sat'd }\end{array}$ & +0.2 & $2 \times 10^{-7}$ & - & - & - & - & 9.7 & Ductile & NC \\
\hline 10 & $\begin{array}{l}\text { Dipa- } \\
\text { Sulfolane- } \\
\text { Water } / \mathrm{CO}_{2} \\
\text { Sat'd }\end{array}$ & -0.1 & $2 \times 10^{-7}$ & 139 & - & 57.6 & 1.0 & 9.7 & Ductile & NC \\
\hline 11 & $\begin{array}{l}\text { Dipa- } \\
\text { Sulfolane- } \\
\text { Water } / \mathrm{CO}_{2} \\
\text { Sat'd }\end{array}$ & -0.2 & $2 \times 10^{-7}$ & 135 & - & 56.4 & 1.0 & 9.7 & Ductile & NC \\
\hline 12 & $\begin{array}{l}\text { Dipa- } \\
\text { Sulfolane- } \\
\text { Water } / \mathrm{CO}_{2} \\
\text { Sat'd }\end{array}$ & -0.5 & $2 \times 10^{-7}$ & 135 & - & 56.4 & 1.0 & 9.7 & Ductile & $N C$ \\
\hline 13 & $\begin{array}{l}25 \% \mathrm{MEA} / \mathrm{H}_{2} \mathrm{O} \\
\mathrm{CO}_{2} \text { Sat'd }\end{array}$ & $\begin{array}{l}E_{\text {corr }} \\
(-0.89 \rightarrow-0.75)\end{array}$ & $1 \times 10^{-6}$ & 20 & $118(772)$ & 28 & 0.6 & 10.0 & $\begin{array}{l}\text { Trans + Inter } \\
\text { Fracture }\end{array}$ & I. $T$ \\
\hline
\end{tabular}


By sweeping the anodic potential region at high rates, zones of high anodic electrochemical activity are defined by the high current response. At very low scan rates the electrochemical activity decreases significantly with time as seen from curve (B) in Figs. 1 and 2. The potential zone which corresponds to drastically different electrochemical activity at different potential sweep rates is likely to be an area of particular sensitivity to $\mathrm{SCC}^{9)}$. $\mathrm{Ex}-$ amination of the potential-current scans in Fig. 1 to 2 indicates that for the $\mathrm{CO}_{2}$ saturated dipasulfolane-water solution this potential zone is -0.5 to $+0.2 \mathrm{~V}(\mathrm{SCE})$ and for the $25 \%$ aqueous dipa solution -0.6 to -0.5 (Table 1 ).

The electrochemical reactivity of carbon steel in both the dipa-water and dipa-sulfolane-water solutions without dissolved $\mathrm{CO}_{2}$ was found to be negligible as determined by means of electrochemical voltametric scans. ${ }^{10)}$

Examination of the potential scans shown in Figs. 1 and 2 show a maximum anodic current density at $1200 \mathrm{mV} / \mathrm{min}$ scan rate within the active electrochemical region for the dipa-sulfolane-water solution of about $8.1 \mathrm{~mA} / \mathrm{cm}^{2}$ and for $25 \%$ dipa-water solution $9.2 \mathrm{~mA} / \mathrm{cm}^{2}$. These data are also summarized in Table 1 in which similar data for $\mathrm{CO}_{2}$ saturated $25 \%$ MEA solutions are also included. Under identical potential scan conditions, the maximum anodic current density for 25\% MEA-water solution is about $35 \mathrm{~mA} / \mathrm{cm}^{2} .{ }^{10)}$ This difference in peak anodic iron dissolution rate between dipa-sulfolane-water and dipa-water solutions as well as 25\% MEA-water solution suggests that the crack propagation rates (assuming anodic dissolution control during crack growth) are likely to be much lower in dipa-sulfolane-water and in dipawater than MEA-water cnvironments.

A series of slow-strain-rate tests were carried out in $45 \%$ dipa- $40 \%$ sulfolane-15\% water and the results are summarized in Table 2. Several slow-strain-rate test were carried out primarily with solutions saturatcd with $\mathrm{CO}_{2}$ (1 atm), at $95^{\circ} \mathrm{C}$ at the free corrosion potential at different strain rates. Carbon dioxide gas was used in these experiments rather than mixtures of $\mathrm{CO}_{2}$ and $\mathrm{H}_{2} \mathrm{~S}$ because previous experiments with MEA solutions have shown pure $\mathrm{CO}_{2}$ to be more aggressive than $\mathrm{CO}_{2}$ and $\mathrm{H}_{2} \mathrm{~S}$ mixtures in promoting SCC of carbon steel. ${ }^{11}$ )

A further series of tests was carried out with the potential controlled in the potential zone +0.2 to $-0.5 \mathrm{~V}$ (SCE) which the electrochemical scans suggest as a potential zone of maximum susceptibility to SCC. Several tests were also carried out with $\mathrm{N}_{2}$ saturated solutions. In addition, test were also run in an inert parafinicbase turbine oil. (Tereso 32, product of Exxon Corp.) for comparison.

The results of these tests are also summarized in Table 2. In tests No. 1 and 2 the solutions were continuously purged with oxygen-free nitrogen during the tests. Test No. 1 was carried out at the free corrosion potential $\left(E_{\text {corr }}\right)$ and test No. 2 at constant potential of $+0.2 \mathrm{~V}$ (SCE). Both tests showed pure ductile behavior. Test No. 3-7 were carried out at the free corrosion potential at different strain rates. Tests 8 to 12 were carried out at a constant potential. For tests 3 to 12 , the solutions which were presaturated with $\mathrm{CO}_{2}$, were also continuously purged with $\mathrm{CO}_{2}$ during the tests.

The tests carried out at the free corrosion potential in $\mathrm{CO}_{2}$ saturated dipa-sulfolane-water solutions at different strain rates (tests No. 3-7) also showed a clearly ductile failure mode with no evidence of cracks in the main fracture surface or secondary cracks in the neck area of the test specimens.

Test No. 8 which was carried out at the fixed potential of $+0.2 \mathrm{~V}(\mathrm{SCE})$ in $\mathrm{CO}_{2}$ saturated solutions also exhibited a ductile fracture. There is, however, some evidence of side cracking shown in Fig. 3. This secondary crack which is at about $45^{\circ}$ to the pulling axes is probably a mechanical tear and not primarily an environmentally induced cracking. Ductile fracture appearance was also observed in Tests No. 9 to 12.

For comparison the results of a typical slowstrain-rate test of carbon steel in $\mathrm{CO}_{2}$ saturated

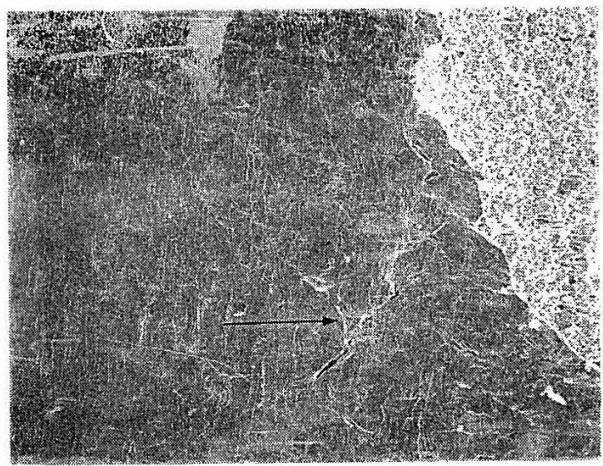

Fig. 3 Side view SEM photomicrograph showing crack near the neckdown area of specimen used in Test No. 8 (Table 2). $160 \times(\times 0.53)$ 
Table 3 Slow-strain-rate tests of carbon steel (AISI 1018) in 25\% dipa-water solutions

\begin{tabular}{|c|c|c|c|c|c|}
\hline $\begin{array}{l}\text { Test } \\
\text { No. } \\
\end{array}$ & $\begin{array}{l}\text { Solut ion } \\
\text { Gas (1 } 1 \mathrm{Atm})\end{array}$ & $\begin{array}{l}\text { Potential } \\
\text { V(SCE) }\end{array}$ & $\begin{array}{c}\text { Strain Rate, } \\
\sec ^{-1}\end{array}$ & $\begin{array}{l}\text { Time to } \\
\text { Failure } \\
\text { (hrs) }\end{array}$ & $\begin{array}{l}\text { Maximum } \\
\text { Stress } \\
\text { ksi (kPa) } \\
\end{array}$ \\
\hline 1 & $\begin{array}{l}25 \% \text { Dipa- } \\
\text { Water } / \mathrm{CO}_{2} \\
\text { Sat'd }\end{array}$ & $-0.5 V$ & $2.8 \times 10^{-6}$ & 14 & $70(482)$ \\
\hline 2 & $\begin{array}{l}25 \% \text { Dipa- } \\
\text { Water } / \mathrm{CO}_{2} \\
\text { Sat'd }\end{array}$ & $-0.6 \mathrm{~V}$ & $2.8 \times 10^{-6}$ & 16 & 72 (496) \\
\hline 3 & $\begin{array}{l}25 \% \text { Dipa- } \\
\text { Water/CO } \\
\text { Sat'd }\end{array}$ & $-0.4 \mathrm{~V}$ & $2.8 \times 10^{-6}$ & 14 & $68(468)$ \\
\hline 4 & $\begin{array}{l}25 \% \text { Dipa- } \\
\text { Water } / \mathrm{CO}_{2} \\
\text { Sat'd }\end{array}$ & $-0.7 \mathrm{~V}$ & $2.8 \times 10^{-6}$ & 16 & 72 (496) \\
\hline 5 & $\begin{array}{l}25 \% \text { Dipa- } \\
\text { Water } / \mathrm{CO}_{2} \\
\text { Sat'd }\end{array}$ & $-0.2 \mathrm{~V}$ & $2.8 \times 10^{-6}$ & 15.5 & $72(496)$ \\
\hline 6 & $\begin{array}{l}25 \% \text { Dipa- } \\
\text { Water/CO } \\
\text { Sat'd }\end{array}$ & $\begin{array}{l}E_{\text {corr }} \\
(-0.88 \mathrm{~V})\end{array}$ & $2.8 \times 10^{-6}$ & 13 & $66(454)$ \\
\hline 7 & $\begin{array}{l}25 \% \text { Dipa- } \\
\text { Water } / \mathrm{CO}_{2}\end{array}$ & $(-0.6)$ & $2 \times 10^{-7}$ & 185 & $54(371)$ \\
\hline \multirow[t]{2}{*}{8} & $\begin{array}{l}40 \% \text { Dipa- } \\
\text { Water/N2 } \\
\text { Sat'd }\end{array}$ & $\begin{array}{l}E_{\text {corr }} \\
(-0.0)\end{array}$ & $2.8 \times 10^{-6}$ & 17 & 76 (432) \\
\hline & $\begin{aligned} N C & =\text { No Cra } \\
I & =\text { Interg } \\
T & =\text { Transg } \\
M T & =\text { Mechan }\end{aligned}$ & $\begin{array}{l}\text { ks } \\
\text { anu lar Crack } \\
\text { anular Crack } \\
\text { cal Tear }\end{array}$ & & & \\
\hline
\end{tabular}

25\% MEA solution is also included in Table 2 (Test No. 13). In addition, Table 2 also includes data on time to failure, percent reduction in area at fracture (RA) and $\mathrm{RA} / \mathrm{RA}_{\text {inert oil }}$, which is the ratio of the percent reduction in area in test solution to that in inert oil. This parameter is an indication of the reduction in dutility. These parameters can also be used as an indication of the ability of an environment to induce stress corrosion cracking. The RA/ $\mathbf{R A}_{\text {inert oil }}$ ratio for tests No. 1 to 12 indicate essentially no significant reduction in ductility, in these tests. However, the effect is significant for the case of MEA (Test No. 13) in which SCC was observed.

The lack of apparent influence of the environment on the main fracture surface and the appearance of essentially no secondary cracks in the neckdown area (where the strain is very high) is an indication of essentially low susceptibility of carbon steel to SCC in the dipasulfolane-water environment under the conditions used in this study. This explanation is supported by the relatively lower anodic electrochemical reactivity of carbon steel in dipa-sulfolane-water solution as compared to that in MEA solution. It is worth noting that MacNab and Treseder ${ }^{12)}$ recommend that major carbon steel equipment operating above $87^{\circ} \mathrm{C}$ in dipa-sulfolane environments be stress relieved in accordance with general practice to stress relieve car-

\begin{tabular}{|c|c|c|c|c|}
\hline $\begin{array}{c}\text { Reduct ion } \\
\text { in Area (RA) } \\
(\%) \\
\end{array}$ & $\left(\frac{R A}{R A}\right)_{\text {inert oil }}$ & $\begin{array}{c}\text { Solution } \\
\mathrm{pH}\end{array}$ & $\begin{array}{c}\text { Fracture } \\
\text { Surface } \\
\text { Appearance } \\
\end{array}$ & $\begin{array}{l}\text { Secondary } \\
\text { Cracking }\end{array}$ \\
\hline 60 & 1.04 & 9.8 & Ductile & NC \\
\hline 60 & 1.04 & 9.8 & Ductile & NC \\
\hline 62.8 & 1.09 & 9.8 & Duct ile & NC \\
\hline 59.4 & 1.03 & 9.8 & Ductile & NC \\
\hline 60 & 1.04 & 9.8 & Duct ile & NC \\
\hline 51 & 0.88 & 9.8 & Ductile & NC \\
\hline 66.4 & 1.14 & 9.7 & $\begin{array}{l}\text { Transgranu lar } \\
\text { Fracture }\end{array}$ & r \\
\hline 62.8 & 1.08 & 11.2 & Ductile & NC \\
\hline
\end{tabular}

bon steel equipment used in amine systems. ${ }^{12)}$ According to the above mentioned authors no stress corrosion cracking of carbon steel equipment in dipa-sulfolane-water solutions has been reported ${ }^{12)}$ although corrosion and blistering in such service has been discussed in the literature. ${ }^{13)}$

A series of slow-strain-rate tests were also carried out with $25 \%$ dipa in water at $95^{\circ} \mathrm{C}$, saturated with $\mathrm{CO}_{2}$ (at $\left.1 \mathrm{~atm}\right)$. The results of these tests are summarized in Table 3. Tests were run at the free corrosion potential and at constant potential in the potential range $-0.7 \mathrm{~V}$ to $-0.2 \mathrm{~V}$ (SCE). The majority of tests were run at a strain rate of $2.8 \times 10^{-6}$. However, one test was also run at $2 \times 10^{-7}$ within the potential range of maximum electrochemical reactivity. At the faster strain rate no cracking was observed either within or outside the potential range of maximum electrochemical reactivity. Clear evidence of transgranular stress corrosion cracking was observed at the slow strain rate of $2 \times 10^{-7}$ at the potential of $-0.6 \mathrm{~V}$ (SCE) which lies within the potential range of maximum electrochemical reactivity (Test No. 7, in Table 3). Pure dipa-water solutions free of dissolved $\mathrm{CO}_{2}$ are not aggressive toward carbon steel and do not cause SCC. Figs. 4 and 5 show the evidence of the SCC observed in Test No. 7 (Table 3). Fig. 4 shows side view microphotographs in cross section showing the 


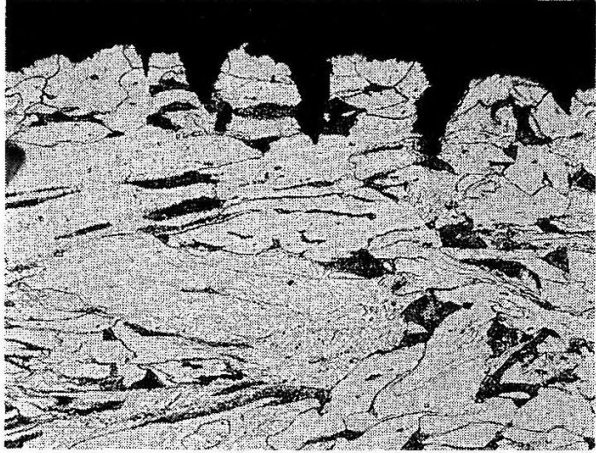

Fig. 4 Side view photomicrograph in cross section showing the transgranular nature of secondary cracks in the neckdown area of specimen Test No. 7, Table 3. $300 \times \times(0.53)$, $2 \%$ nital

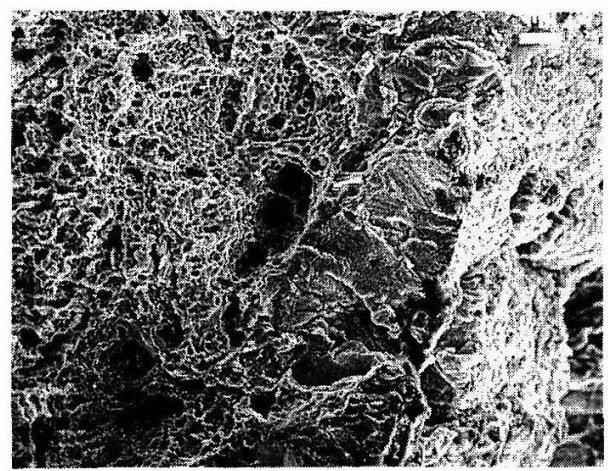

Fig. 5 SEM photomicrograph of fracture surface of specimen Test No. 7, Table 3, showing the transgranular appearance of the main crack on fracture surface. $700 \times(0.53)$

transgranular nature of secondary cracks observed. Fig. 5 shows the transgranular morphology of a crack observed in the main fracture surface.

The absence of SCC in the Test No. 2 (Table 3 ) indicates that the crack growth rate of carbon steel in aqueous dipa-solutions is probably fairly slow for a crack to grow to detectable size during the test period of about 16 hours. However, at considerable slower strain rates, $(2 \times$ $10^{-7}$, Test No. 6) there is apparently sufficient time for cracks to nucleate and grow to detectable size. After this experimental work was completed P. Aaltonen, et al. ${ }^{14)}$ reported plant experience as well as laboratory data indicating stress corrosion cracking of carbon steel in aqueous-dipa solutions containing $\mathrm{CO}_{2}$ and $\mathrm{H}_{2} \mathrm{~S}$. These authors reported both transgranular and intergranular cracking with solutions of different $\mathrm{pH}$ values at different potentials. Under the experimental conditions used by these authors cracking both transgranular and intergranular was observed in lean dipa solutions containing $\mathrm{CO}_{2}$ and some $\mathrm{H}_{2} \mathrm{~S}$.

\section{Conclusions}

Based on the results discussed in this report the following conclusions can be drawn:

(1) Dipa-sulfolane-water solutions and aqeous solution containing only dipa which do not contain dissolved $\mathrm{CO}_{2}$ do not cause SCC of carbon steel.

(2) Solutions of dipa-sulfolane-water which contain dissolved $\mathrm{CO}_{2}$ also show no tendency for SCC both at the free corrosion potential and in potentials of maximum electrochemical reactivity, under the conditions used in this study.

(3) Aqueous solutions containing only dipa (at 25 wt $\%$ ) saturated with $\mathrm{CO}_{2}$ at $95^{\circ} \mathrm{C}$ were found to cause SCC of carbon steel in the potential range of maximum anodic electrochemical reactivity $-0.6 \mathrm{~V}$ (SCE).

(4) The probable explanation of the lack of SCC response in the dipa-sulfolane-water solutions tested is that either the crack initiation or the crack growth rate is fairly slow, in comparison with either aqueous dipa or the MEA solutions, for a crack to grow to detectable size during the test period.

\section{Acknowledgements}

The author wishes to acknowledge the technical assistance of D. Rewick and D. C. Lattig, who performed all of the experimental work.

(Reccived January 14, 1992)

\section{References}

1) A. L. Kohl \& F. C. Riesenfeld: "Gas Purification" McGraw-Hill Co., New York, N.Y. 3rd Edition.

2) C. H. Deal, G. L. Dunn, E. S. Hill, M. N. Papadopoulos \& K. E. Zalker: Proceedings 6th World Petroleum Congress, Section IV, Paper 32, Frankfurt, Germany, June (1963).

3) C. L. Dunn, E. R. Freitas, J. W. Goodenbour, H. T. Henderson \& M. N. Papadopoulos: Petroleum Refiner, 43, No. 3, 150 (1964).

4) D. G. Hughes: Proceedings 1982 UK Corrosion Conference, p. 85, November (1982).

5) J. H. Payer, W. E. Berry \& W. K. Boyd: in "Stress Corrosion Cracking-New Approaches," ASTM STP 610, American Society for Testing and Materials, p. 82, (1976).

6) Z. A. Foroulis: J. Electroch. Soc., 113, 532 
(1966).

7) Z. A. Foroulis: Boshku Gijutsu, 36, 617 (1987).

8) Z. A. Foroulis, ibid., 38, 9 (1989).

9) R. N. Parkins: Corrosion Science, 20, 147 (1980).

10) Z. A. Foroulis: unpublished data.

11) R. N. Parkins \& Z. A. Foroulis: Mat. Perf., 22, 19 (1983).
12) A. J. MacNab \& R. S. Treseder: Mat. Perf., 10, 21 (1971).

13) W. R. Schmeal, A. J. MacNab \& P. R. Rhodes: Chem. Eng. Progr. 37 (1978).

14) P. Aaltonen, H. Hanninen, L. Tanskanen \& K. Rintamaki: in "Corrosion Prevention in Process Industries" ed. by R. N. Parkins, NACE, Houston, TX (1990). 